\title{
Vowel-consonant metathesis in Nivaĉle
}

\author{
ANALÍA GUTIÉRREZ \\ Consejo Nacional de Investigaciones Científicas y \\ Técnicas - Universidad de Buenos Aires \\ analiagutierrez@conicet.gov.ar
}

\begin{abstract}
Vowel-consonant metathesis is observed in a variety of contexts throughout the Nivacte (Mataguayan) grammar. It occurs in both verbal and nominal domains, characteristically resulting from the affixation of a consonant-initial suffix to a consonant-final stem. This paper provides an optimality theoretic account for vowel-consonant metathesis and vowel epenthesis in Nivaĉle. It is demonstrated that metathesis responds to phonological requirements; specifically, it serves to avoid marked structures in the language: complex codas, derived complex onsets, and bad syllable contacts. The prosodic analysis of syllable structure constraints aims to provide broad empirical coverage, as well as a coherent and integrated theoretical interpretation.
\end{abstract}

Keywords: metathesis, epenthesis, phonology, Nivaĉle

\section{Résumé}

La métathèse voyelle-consonne a été observée dans divers contextes dans la grammaire du nivaclé (mataguayo). Elle se produit dans les domaines verbaux ainsi que dans les domaines nominaux, et est typiquement le résultat de l'affixation, à une base à consonne finale, d'un suffixe à consonne initiale. Cet article offre une analyse de la métathèse voyelle-consonne et de l'épenthèse vocalique en nivaclé, dans le cadre de la Théorie de l'optimalité. On démontre ici que la métathèse constitue une réponse aux contraintes phonologiques; spécifiquement, il sert à éviter l'émergence des structures marquées dans la langue: codas

First and foremost, I would like to express my sincere gratitude to my consultants Félix Ramírez Flores, Sara Rojas Núñez, Teresita Sánchez, Graciano Ramírez, and Raquel Fleitas González for teaching me their language with patience and generosity. Many thanks to Patricia A. Shaw for her very valuable and detailed comments on drafts of this work. I am also grateful for the help of three anonymous reviewers, whose insights and suggestions improved this paper. Any remaining errors are my own. My fieldwork research was funded by the Jacobs Research Funds (Whatcom Museum, 2010), the Bottom Billion Fieldwork Fund (Liu Institute for Global Issues, University of British Columbia, 2011), and a Small Grant from the Endangered Languages Documentation Programme (School of Oriental and African Studies, University of London, 2012). I sincerely thank each of these sources for supporting my work. 
complexes, attaques complexes dérivées, et mauvais contacts entre syllabes. L'analyse prosodique des contraintes sur la structure syllabique vise à offrir une large couverture empirique, ainsi qu'une interprétation théorique à la fois intégrée et cohérente.

Mots clés: metáthèse, épenthèse, phonologie, Nivaĉle

\section{INTRODUCTION}

Metathesis has been defined as a process in which "under certain conditions, sounds switch positions with one another" (Hume 2001: 1). It has long been considered to be sporadic or irregular in comparison with other phonological processes such as assimilation, epenthesis, and deletion. A commonly cited factor that has played against a unified account of metathesis is the direction of change: certain sounds can be reordered in one way in one language but in the exact opposite way in another language. According to Hume (2004: 204), these are probably some of the reasons metathesis has not received much attention in the literature until recently, when both cross-linguistic surveys (Blevins and Garrett 1998, 2004; Mielke and Hume 2001; Hume 2004; Buckley 2011, among others) and analyses of individual languages (Hume 1991, 1998; Coetzee 1999; McCarthy 2000; Hume and Seo 2004; Buckley 2007; Czaplicki 2009; Hannahs 2009, 2011; Crowhurst and Trechter 2014; Faust 2014; Edwards 2018, among others) have reopened the debate about the nature and treatment of metathesis. ${ }^{1}$

Vowel-consonant metathesis is observed in a variety of contexts throughout the Nivaĉle (Mataguayan) grammar. It occurs in both verbal and nominal domains, characteristically resulting from the affixation of a consonant-initial suffix to a consonantfinal stem. The following examples illustrate metathesis in noun pluralization.
(1) a. fináx 'crab'
b. finxá-s
crab-PL
*fináx-s
'crabs'
(2) a. fin-ćk
suck-RES
'tobacco'
suck-RES-NMLZ
'smoker'
b. fin-ka-náx *fin-ak-náx

In this paper, I provide an Optimality Theory account (McCarthy and Prince 1995, Prince and Smolensky 2004) of vowel-consonant metathesis and vowel epenthesis in Nivaĉle. My major claim is that Nivaĉle metathesis is driven by two syllable

\footnotetext{
${ }^{1}$ Abbreviations used in this paper include: 1: first person; 3: third person; AG: agentive; AR: area; BEN: benefactive; CAUS: causative; DET: determiner; F: feminine; HUM: human; INDEF: indefinite; KIN: kinship; LOC: locative; MALEF: malefactive; N.HUM: non-human; NMLZ: nominalizer; NOM: nominative; PL: plural; POSs: possessive; RES: resultative; s: subject; vBLZ: verbalizer.
} 
requirements: (a) the avoidance of complex codas, and (b) the satisfaction of the Syllable Contact Law (Hooper 1976, Murray and Vennemann 1983, Vennemann 1988, Gouskova 2004). Vowel epenthesis occurs when VC-metathesis would yield illicit consonant clusters. I also discuss a previous proposal for Nivaĉle within a diachronic framework (Campbell and Grondona 2007) and consider alternative analyses such as pseudometathesis (Blevins and Garrett 2004).

This article is structured as follows. Section 2 presents an overview of the Nivaĉle phonological system and the problem of Nivaĉle alternating forms in the context of affixation processes, (i.e., when consonant-initial suffixes are attached to consonant-final stems). Section 3 provides an Optimality Theory analysis for VC-metathesis in Nivaĉle, where I argue that the avoidance of complex codas and the satisfaction of the Syllable Contact Law are the driving forces behind this phenomenon. Section 4 discusses the domain in which metathesis occurs, that is, the root. Section 5 discusses the broader context of historical sound change and pseudometathesis. Finally, section 6 summarizes the main conclusions of this paper.

\section{The Nivaĉle PHONEMIC INVENTORY AND BASIC PHONOTACTICS}

Nivaĉle [nißak̂é] is a Mataguayan language spoken in the Argentinean and Paraguayan Chaco, with approximately 14,768 speakers in Paraguay (DGEEC 2012) and 500 in Argentina (INDEC 2004-2005). The Chorote, Maká, and Wichí languages, which also belong to the Mataguayan family, occupy the nearby regions. The location of the Mataguayan languages and peoples spans Northeastern Argentina, Southeastern Bolivia, and Southwestern Paraguay, in the region known as the Gran Chaco. The work described in this article builds on a larger documentation project that took place in the Nivaĉle communities of $U_{j}$ 'e Lhavos and Santa Teresita (Paraguayan Chaco) between 2009 and 2013.

The phonemic inventory of Nivaĉle is quite stable across all of its varieties, with six vowels and twenty-one consonants. The vowels are /i e a a o u/. The central vowel /a/ patterns with the front vowels /i/ and /e/ in processes of palatalization. In addition to these plain vowels, Stell (1987: 97) postulates a phonemic contrast with the glottalized vowels $\underset{\sim}{\mathrm{i}} \underset{\sim}{\mathrm{e}} \underset{\sim}{\mathrm{a}} \underset{\sim}{\mathrm{a}} \underset{\sim}{\mathrm{O}} \underset{\sim}{\mathrm{u}}$ /. I propose instead that Nivaĉle glottalized vowels are underlying sequences of $/ \mathrm{V} P /$ and, given that there is a consistent correlation between glottalized vowels and the locus of stress, that a postvocalic glottal stop is underlyingly moraic. If the glottal segment is aligned with the right edge of the syllable domain, the glottal stop will be parsed directly to the syllable node as a coda (3a). On the other hand, if there is another consonant intervening between the glottal stop segment and the right edge of the syllable, then the mora (and its associated $/ \mathrm{P} /$ features) will be parsed directly into the nucleus of the syllable ( $3 \mathrm{~b})$. In other words, only if the coda position is already filled by another consonant will the glottal stop be parsed into the nucleus; a complex nucleus emerges at the expense of not creating a complex coda (an illicit syllable structure in this language).

There are thus two phonetic manifestations of underlying /VP/ sequences; (i) a vowel-glottal coda sequence [V?] (3a), and (ii) creaky [V] (3b). 
(3) a. /jita?/

[jitá?]

'scrubland'

b. /אlo?p/

[k̄óp]

'winter'

Because the variable prosodic parsing of the Nivaĉle postvocalic glottal stop has effects on the syllable structure (i.e., creating either closed syllables or complex nuclei), in this article I maintain the separate transcriptions above of these two types of phonetically-glottalized vowels. I provide both phonemic and phonetic transcriptions wherever necessary.

Table 1 presents the 21 phonemic consonants of the language. The segments in square brackets represent allophonic variants of the segments to their left. Transcriptions in this article generally follow IPA conventions, but primary stress will be represented with an acute accent and secondary stress with a grave accent.

Like other Mataguayan languages, Nivaĉle has a two-way laryngeal distinction in non-continuant obstruents (plain vs. ejectives) - except for the complex segment $/ \mathrm{kl} /$ - but no voicing contrast. Nivaĉle also displays a typologically unique lateral system. There are two lateral obstruents: the lateral fricative $/ 4 /$ and the complex segment $/ \mathrm{kl} /$, but no lateral approximant. It has been argued (Gutiérrez 2019) that the complex segment $/ \mathrm{kl} /$ is neither an affricate (there is no fricative release and the sequence of two phases does not agree in voicing), nor a consonant cluster. This complex segment consistently simplifies to [k] in coda position.

The core syllable structures in Nivaĉle are CV, CVC, CCV and CCVC. There are no onsetless syllables in the language, either word-initially or word-medially, and the glottal stop serves as the preferred epenthetic consonant.

All Nivaĉle consonants may appear as singleton onsets or codas, except for the ejectives /p' t' k' ts' T⿱ '/ which occur only in onsets. Several authors (Itô 1986, Itô and Mester 1994, Lombardi 1995) have pointed out a crosslinguistic restriction against LARYNGeAl and Place occurring jointly in coda position. In that regard, Nivaĉle ejectives neutralize to their plain counterparts in this syllabic position.

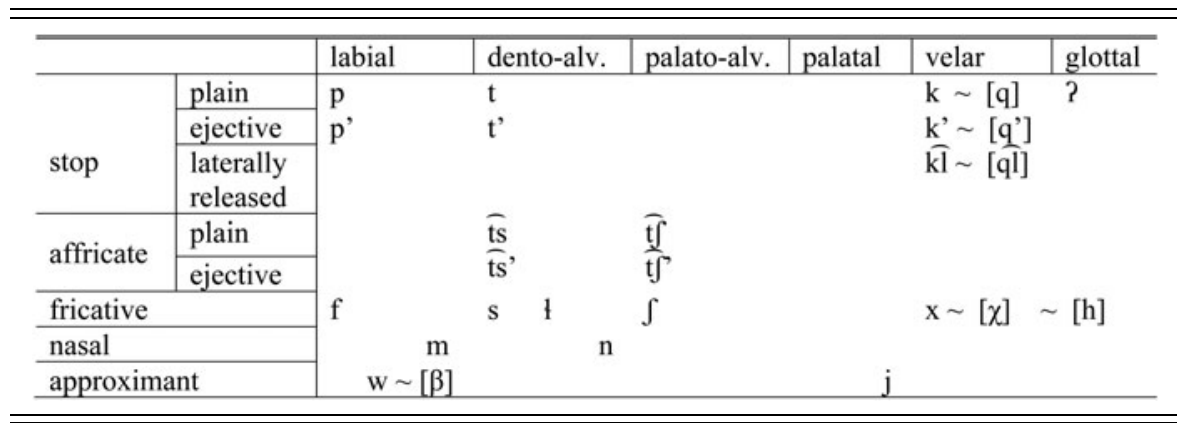

Table 1: Nivaĉle consonants 


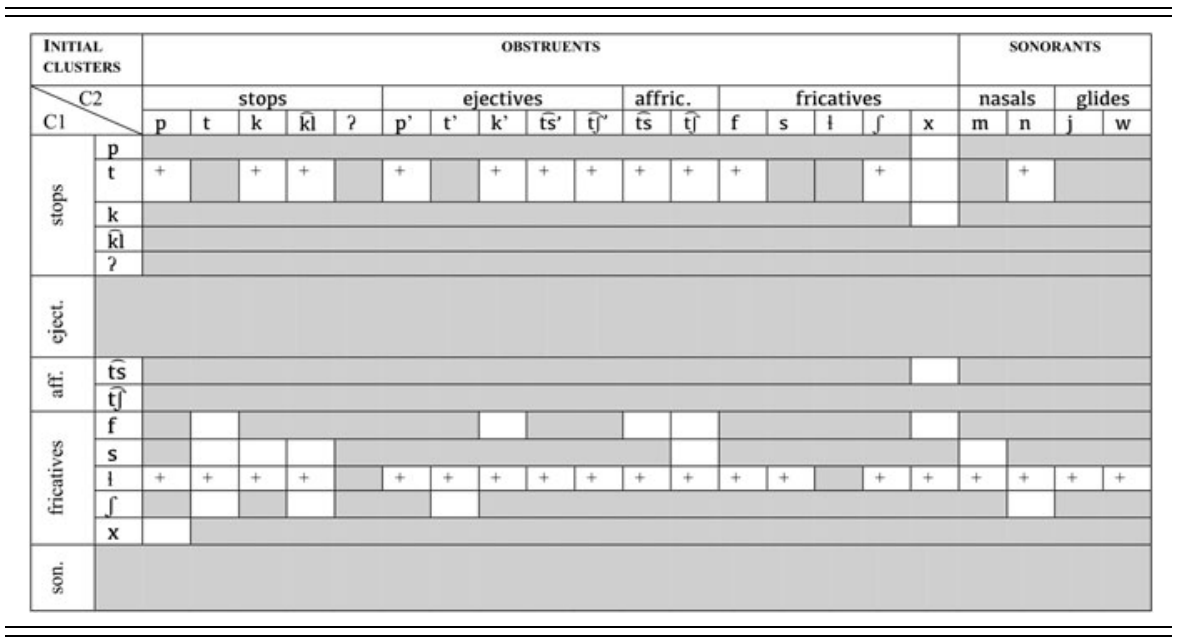

Table 2: Initial CC Clusters in Nivaĉle ${ }^{2}$

Onset clusters (at most two consonants) can occur in word-initial position; coda clusters are never attested. Tables 2 and 3 show the permissibility of consonant clusters in word-initial and word-medial position. These data were taken from Seelwische's (1990) dictionary and my own fieldwork. The set of segments heading the rows indicates the first element of the cluster (C1), and the set of segments heading the columns indicates the second element (C2). While empty cells indicate attested clusters, grey cells indicate unattested clusters. In Table 2, the (+) sign indicates that the sequence is only attested across a morpheme boundary.

Nivaĉle initial clusters do not involve traditional branching onsets with a rise in sonority (e.g., tj, tw), but they never show a sonority fall either; there are no sonorantobstruent $(* \mathrm{SO})$ sequences (i.e., *Nasal/Glide-Obstruent). However, there can be obstruent-obstruent sequences, as illustrated by the fricative (C1) + stop/ejective/ affricate/fricative (C2) sequences. In fact, fricatives are the least constrained members of CC-initial clusters.

The following examples show word-initial clusters in alienable nominal roots that is, roots that do not require the presence of an obligatory possessive prefix - and predicative verbs:

(4) a. pxuxúk 'cactus'

b. txóp 'temperate'

\footnotetext{
${ }^{2}$ The coronal stop / $/$ / and the lateral fricative / $\mathrm{q} /$ can occur before segments of all types, but only across morphemic boundaries.
} 


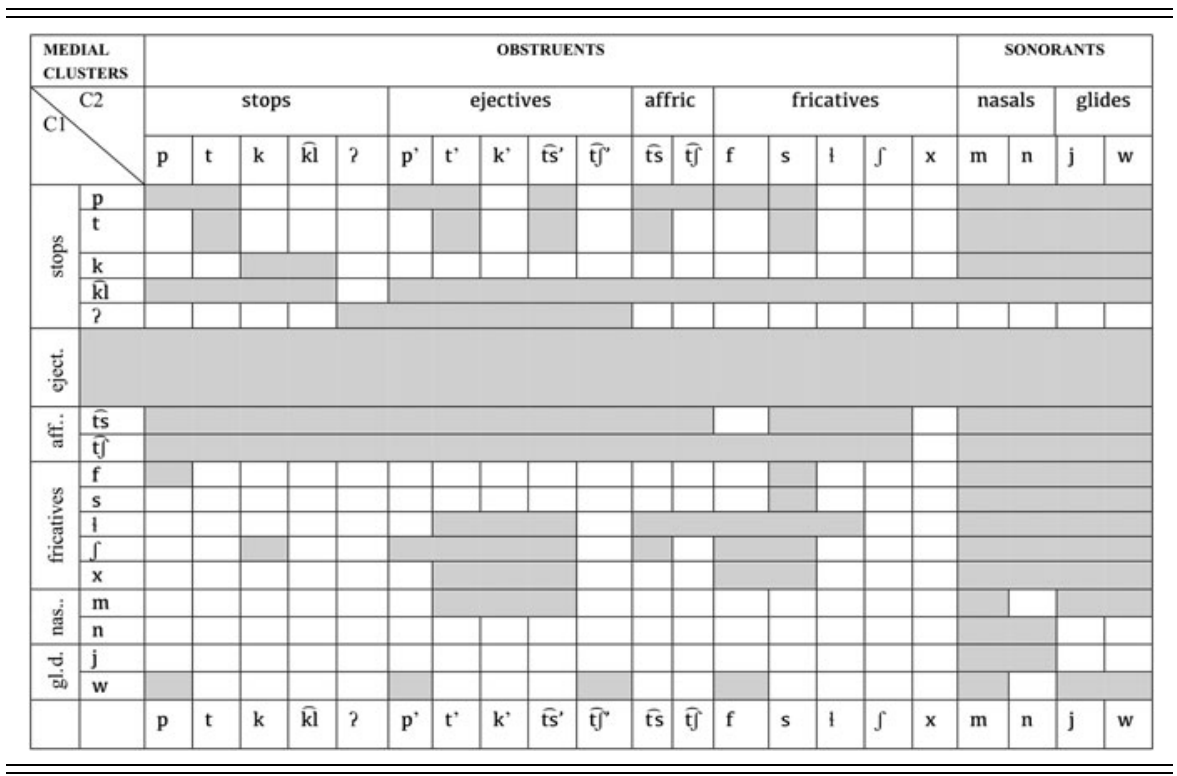

Table 3: Medial CC Clusters

c. kxám

'just'

d. Jk̄lakxáj $\sim$ sḳ̂lakxáj 'wild cat'

e. fk'atsáx

'wide'

f. /ftsú?k/

[ftsứk]

'palm tree'

g. /xpa?k/

[xpák]

'straw'

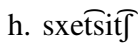

'owl'

i. Jnawáp

'spring'

j. swuk̂̄áx

'anteater'

Note that examples with initial \#pC, \#fC, \#xC are provided for completeness here, but that these in fact are extremely rare clusters. The pervasive 
generalization is that $\mathrm{C} 1$ of an initial CC cluster is Coronal, consistent with Morelli (1999, 2003).

Ejectives and affricates cannot occur as the first member of an initial cluster (except for [ $\overparen{\mathrm{ts}}$ ], which can precede [x]). However, as seen in (4e), [fk'atsáx] 'wide', ejectives can occur as the second member of an initial cluster. Given that CCC clusters are not allowed, the initial onset cluster [fk'] provides evidence against treating ejective consonants as $\mathrm{C}+?$ sequences.

Further, a major set of distributional generalizations of word-medial clusters that plays an important role in my analysis is that where there is a word-internal coda, the following onset is always of equal or lesser sonority; that is, Obstruent(O)-Sonorant (S) sequences are not attested in the Stem1 (St1) domain. I consider the St1 to consist of the root and derivational suffixes.

The notion of sonority thus provides a window into the fact that different layers of affixes define different prosodic domains. Example (2b), fin-ka-náx 'smoker', consists of a single St1, while example $\left(2 b^{\prime}\right)$, *fin-ak-náx, illustrates that an obstruentsonorant sequence across a syllable boundary within this domain is actively and systematically avoided within the phonology of Nivaĉle (as I will further explore in section 3.2.2). However, there are other contexts where such contact persists without being subject to metathesis (or any other repair strategy):

(5) \&-tế $=\mathrm{ji}$

2.s-say-1.o

'you tell me'

In (5), the palatoalveolar fricative $/ \mathrm{J} /$ in the coda precedes the palatal glide $/ \mathrm{j} / \mathrm{in}$ the following onset, leading to a bad syllable contact. I hypothesize that in cases where such sequences persist, they are permitted to do so because there is a stronger prosodic boundary between them. Specifically, in (5), the first-person object pronoun is a clitic. The generalization governing metathesis is that it operates within an inner prosodic domain, identified as the St1, but it does not apply in the outer domain; that is, the higher Prosodic Word domain that contains clitics. ${ }^{3}$

Finally, Nivaĉle has a quantity-sensitive iambic stress system. There is a consistent correlation between bimoraic weight (tautosyllabic /V?/) and stress prominence. In addition, primary/secondary stress patterns reflect competing edge-alignment constraints where prosodic foot domains align with internal morphological category (MCat) edges, specifically Root (Rt), Stem1 (St1), Stem2 (St2), and Morphological Word (MWd). For a fuller explanation of Nivaĉle stress assignment domains, see Gutiérrez (2015).

\footnotetext{
${ }^{3}$ There is a diverse set of prosodically-sensitive phonological constraints - including the Syllable Contact Law and metathesis (section 3.2.2) - that all demonstrably apply within a well-defined morpho-prosodic domain (the Stem1) that is not fully co-extensive with the Prosodic Word, but rather is internal to it. These constraints constitute a significant body of empirical evidence demonstrating that the prosodic phonology needs "inside access" to morphological domain structure in the sense of Shaw (2009).
} 


\subsection{The problem: alternating vs. non-alternating forms}

As mentioned above, the phenomenon of metathesis is observed in a variety of contexts throughout the Nivaĉle grammar. It occurs in both nominal and verbal domains, characteristically resulting from the affixation of a consonant-initial suffix to a consonant-final stem. The focus of this section is pluralization in the nominal domain.

Pluralization of nouns in Nivaĉle exhibits a considerable degree of allomorphy, where the choice of allomorph is lexically determined rather than phonologically conditioned. The basic noun plural allomorphs are $/-\mathrm{s} / \sim /-\mathrm{j} / \sim /-\overline{\mathrm{k}} /$ (the latter surfaces as $[\mathrm{k}]$ in word-final position). The data presentation below is organized into four sets (section 2.1.1 through section 2.1.4) that illustrate the different patterns of phonological alternations in nominal stems suffixed by these plural allomorphs.

\subsubsection{Noun plurals: Non-alternating V-final noun stems}

The V-final stems in (6)-(11) illustrate the plural allomorphy in Nivaĉle: each of the three suffixes occurs after all vowel qualities (the list in (6)-(11) is not exhaustive).

(6)
a. 4-a
F-DET
ßot'í
'a/the turtle'
turtle

b. na- $\beta \mathrm{a}$

ßot'í-s

DET-PL.N.HUM turtle-PL

'(the) turtles'

(7)
a. na
ałú
DET
lizard
' $\mathrm{a} /$ the lizard'
b. na- $\beta a$
ałú-s
DET-PL.N.HUM lizard-PL
'(the) lizards'
(8) a. na kasuts'i
DET armadillo
'a/the armadillo'
b. /na-wa kasuts'î- $\widehat{\mathrm{k} l} /$
[na- $\beta$ kasuts' 1 -k]
DET-PL.N.HUM armadillo-PL
'(the) armadillos'
(9) a. na k̂ klesá
DET knife
' $a$ /the knife'

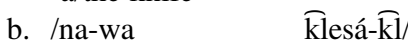
[na-ßa klesá-k]
DET-PL.N.HUM knife-PL




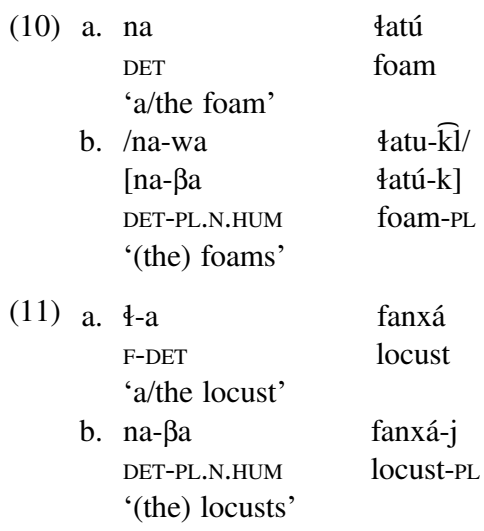

Further, even though only looking at a few pairs of data in Nivaĉle would suggest a correlation of $-s$ with masculine nouns and $-j$ with feminine nouns (see (12)-(13) below), the range of data presented in this article establishes that all three suffixes occur with both masculine and feminine roots. The epenthetic vowel in (13) is shown in square brackets. Non-human nouns are not marked for gender; feminine and masculine gender is marked on the singular determiner forms. In contrast, plural determiner forms differentiate between 'human' ([-pi], as in (12-13)) and 'non-human' ([- $\beta \mathrm{a}]$, as in $(6 \mathrm{~b}-11 \mathrm{~b}))$.
a. na-pi
DET-PL.HUM
'the elders'
b. na-pi
DET-PL.HUM
'the female elders'
k'utšxá-j
elder-PL
k'utsxá-s
elder-PL
(13) a. na-pi
DET-PL.HUM
'the boys'
b. na-pi
DET-PL.HUM
'the girls'
nèkxak-[í]s
boys-PL
nèkxak-é-j
boy-F-PL

There is also a -CVC plural suffix /-wot/ (14b) which is restricted to kinship terms. However, its usage is currently undergoing attrition, as it is starting to alternate with other plural suffixes: ${ }^{4}$

\footnotetext{
${ }^{4}$ Also, it is worth noting the existence of intra- and inter-speaker variation in the selection of the consonantal plural allomorphs, as shown in (i):

$\begin{array}{lll}\text { (i) a. } \begin{array}{l}\text { ófo-s } \\ \text { dove-PL } \\ \text { 'doves' }\end{array} & \sim & \begin{array}{l}\text { ófo-k } \\ \text { dove-PL }\end{array} \\ \text { b. } \begin{array}{l}\text { ftaklé-s } \\ \text { rubbish-PL } \\ \text { 'rubbish' }\end{array} & \sim & \begin{array}{l}\text { ftaklé-j } \\ \text { rubbish-PL }\end{array}\end{array}$
}


(14) a. ji-t]ín.xa

1.POSs-younger.sister

'my younger sister'

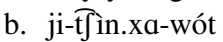

$\sim$ ji-t $\int \hat{i n} . x a-s$

1.POSS-younger.sister- KIN.PL

'my younger sisters'

1.POss-younger.sister- PL

'my younger sisters'

\subsubsection{Noun plurals: Glottal-final stems}

The following data show that noun stems with a final glottal stop systematically lose that glottal stop when suffixed by the plural. Note that this deglottalization is triggered by all allomorphs of the plural suffix.

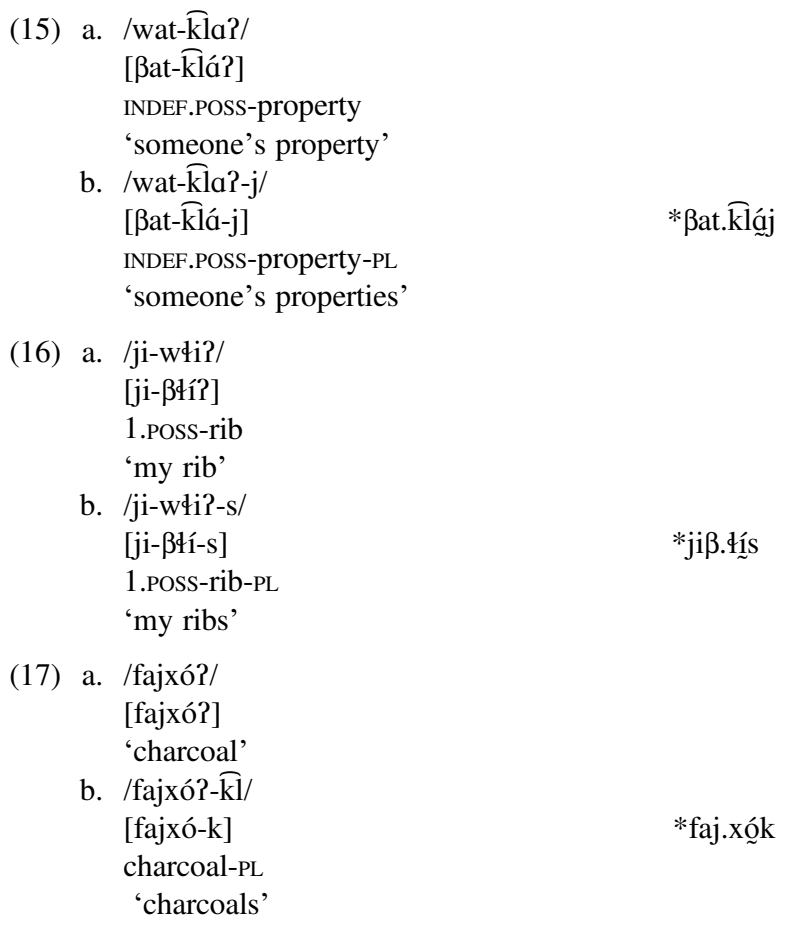

The deletion of the glottal is morphologically conditioned. In (3b), it was shown that in an underlying V?C root sequence (e.g., / / lo?p/), the glottal can be parsed to the
c. j-as-é-j
j-as-é-k
1.POSS-Son-F-PL
1.POSS-Son-F-PL
'my daughters'

This kind of variation is expected under the hypothesis that the plural allomorphy is not phonologically conditioned, but rather lexically conditioned. Concomitantly, plural markers in nouns can get omitted; however, plurality is still recoverable from the determiners, in a similar way to gender. 
nucleus of the syllable and thus be realized as a glottalized vowel: [klóp]. With this parsing, there is no violation of the complex coda restriction: *[klo?p]. In contrast, the glottal does not get realized as a glottalized vowel when a consonant-initial plural suffix is attached to the root (15b-17b). The consistent pattern is that it cannot occur in either non-metathesized (15-17) or metathesized forms (see (20) below), under nominal plural suffixation. ${ }^{5}$ Interestingly, deletion of stem-final glottals in the context of nominal pluralization is also regularly attested in two other Mataguayan languages. For example, in Chorote we see awo? 'worm', awo-s 'worms' (Gerzenstein 1983: 50); and in Maká we find witkinxe? 'hip/side', witkinxe-j 'hips/sides' (Gerzenstein 1999: 231).

\subsubsection{Noun plurals: Metathesis in C-final stems}

As illustrated in (18)-(22), the forms exhibiting metathesis are all consonant-final in their unsuffixed singular form: the particular stem-final consonants known to participate in the metathesis process are $/ \mathrm{t} \mathrm{\tau} \int \mathrm{k} \mathrm{x} /$, although, on the basis of the hypotheses advanced in section 3 below, it is predicted that any stem-final obstruent would participate in metathesis, under the appropriate triggering conditions. The metathesis itself can be characterized as follows: the final vowel and consonant of the unsuffixed stem in (18a)-(22a) switch their linear order when the plural suffix is attached in (18b)-(22b). Schematically, then, the segments $V_{1}$ and $C_{2}$ are reordered with the addition of the plural consonantal suffix $-\mathrm{C}: \mathrm{V}_{1} \mathrm{C}_{2}-\mathrm{C} \rightarrow \mathrm{C}_{2} \mathrm{~V}_{1}-\mathrm{C}$. For example, the plural of 'my job' in (18a) is not *ßàt-ku.mét-s, but $\beta$ àt-kumté-s. The starred examples show the ungrammatical (non-metathesized) forms with unpermitted complex codas.

(18) a. Bàt-kum-ét

INDEF.POSS-Work-NOM

'my job'

b. ßàt-kum-té-s *ßàt-ku.mét-s

INDEF.POSS-Work-NOM-PL

'my jobs'

(19) a. ap'áx

'yarara (pit viper)'

\footnotetext{
${ }^{5}$ In contrast, the following example shows that a glottalized vowel can be realized in a metathesized context under derivational suffixation (the derivational suffix /-p/ means 'season'). The deletion of the glottal stop is thus morphologically and not phonologically conditioned:
}

(i) a. $/ \operatorname{tisu} 3 x /$

[tisúx]

'coronillo tree'

b. /tisu?x-p/

[tisxú́-p] see [tisxú-j] (20b)

coronillo.tree-season coronillo.tree-PL

'season when the coronillo tree blossoms (autumn)' 
b. apxá-s

yarara-PL

'yararas (pit vipers)'

(20) a. /tisu?x/

[tisúx]

'coronillo tree'

b. tisxú-j

coronillo.tree-PL

'coronillo trees'

(21) a. ßat-ák

3.INDEF.POSS-meal

'somebody's meal'

b. ßat-ká-s

3.INDEF.POSS-meal-PL

'somebody's meals'

(22) a. fin-ák

suck-NMLZ(RES)

'tobacco'

b. fin-xá-j

suck-NMLZ(RES)-PL

'tobaccos' *a.p'áx-s

*ti.sú.x-j

*ßa.ták-s

*fi.nák-j

The reordering of segments within the phonological string triggers some featural changes such as deglottalization of ejectives (19) and glottalized vowels (20), and the spirantization of the dorsal stop present in the nominalizer suffix (22). ${ }^{6}$

\subsubsection{Noun plurals: C-final stems with Vowel epenthesis}

The final set of data shows C-final noun stems which are not subject to metathesis, unlike the examples seen in section 2.1.3; rather, a vowel is epenthesized between the final $\mathrm{C}$ of the stem and the plural suffix. The first starred forms show the

\footnotetext{
${ }^{6}$ One of the anonymous reviewers asks about the phonemic difference between the dorsals in 'meal' and in the 'nominalizer' suffix. Synchronically, it is not very clear whether there is a phonemic distinction between velar [k] and uvular [q] in Nivaĉle (to the best of my knowledge, there are no clear minimal/near minimal pairs). However, it could be posited that the dorsal in 'meal' historically comes from Proto-Mataguayan *q (e.g., Maká: - $a q$ 'meal' (Gerzenstein 1999: 434), Wichí/Weenhayek: -aq (Claesson 1994: 12), Chorote: -ak (Gerzenstein 1983: 118)), whereas the dorsal in the 'nominalizer' suffix comes from *k (e.g., Maká: fin-ak 'tobacco', fin-hay 'tobaccos'; niy-ak 'rope', nii-hay 'ropes' (Gerzenstein 1999: 176, 275). Campbell and Grondona (2007: 18) entertain the hypothesis that Proto-Mataguayan originally had a contrast between uvular and velar stops. Furthermore, in her reconstruction of the ProtoMataguayan phonology, Najlis (1984:8) proposes the existence of two dorsal proto-phonemes: *k and * q. As a result, a dissimilar behaviour between the Nivaĉle dorsals could be hypothesized; only those that historically descend from *k show spirantization.
} 
ungrammatical forms with complex codas, and the second starred forms show the potential, but not attested, metathesized forms.

(23) a. / /klo?p/

[klōp]

'winter'

b. Klop-[í]s

winter-PL

'winters'

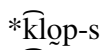

*k̂ेpo-s

(24) a. tós

'snake'

b. tos-[1]]s

snake-PL

*tos-s

'snakes'

*tso-s

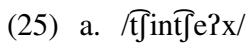

[t]intféx]

'spirit'

b. đ̂tîntfex-[í]s

spirit-PL

'spirits'

(26) a. Jk̂lakxáj

'wild cat'

b. Jk̄ákxaj-[í]s

$* \int^{*} 1 *$.xaj-s wild.cat-PL

'wild cats'

$* \mathrm{t}^{*}$ n. $\mathrm{t}$.t. $\mathrm{t}-\mathrm{s}$

* t* n. n. T.t-s

*f* $1 *$ k.xja-s

(27) a. makók

'frog'

b. makok-[1] k

frog-PL

'frogs'

(28) a. kasús

'pumpkin'

b. kasus[í]k

pumpkin-PL

'pumpkins'

*ma.kó.k-k

*mak.ko-k

These forms raise the following analytic question: what differentiates the $\mathrm{C}$-final forms in (18-22) from the C-final forms in (23)-(28)? While this question will be discussed at greater length in section 3, for now it is sufficient to note that although metathesis would function to repair an ill-formed complex coda in word-final position (as shown in the first starred forms in (23-28)), it would result in the creation of an ill-formed consonant cluster (as shown in the second starred forms in $(23-28)){ }^{7}$ Vowel epenthesis thus emerges as an alternative repair mechanism.

\footnotetext{
${ }^{7}$ Another question revolves around the quality of the epenthetic vowels seen in the data above. Whereas the epenthetic vowel most commonly used with the $-s$ and $-k$ allomorphs is $/ \mathrm{i} /$, the epenthetic vowel [e] is also occasionally found, though to a much lesser extent. The
} 
As shown in the examples above, the epenthetic vowel most commonly used with the $-s$ and $-k$ allomorphs is [i]. There is yet another pattern of epenthesis manifested in a very small subset of the data in my field corpus, where the epenthetic vowel matches the last vowel of the root.

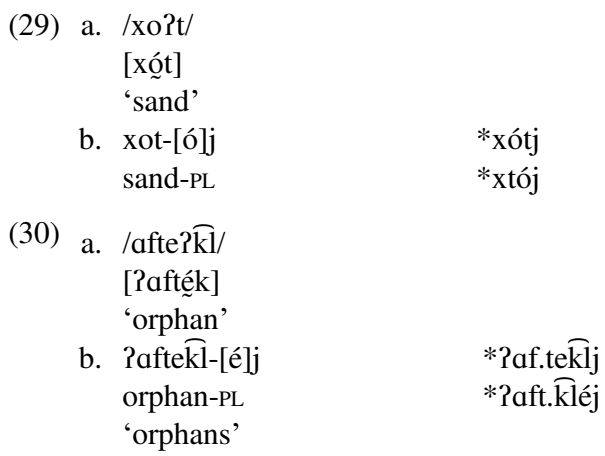

Harmonic epenthetic vowels are much less frequent than [i] or [e] epenthesis, and they occur most frequently with the [j] plural allomorph. Another case of harmonic epenthetic vowel can be found with the kinship plural suffix /-wot/, as in (31b), which is restricted to a limited set of terms and is currently subject to both variation and attrition.

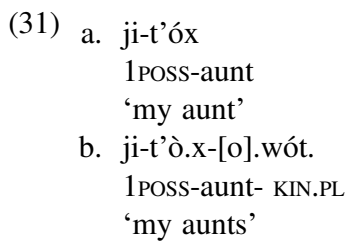

While it is not possible on the basis of the available data to predict which epenthetic vowel will appear, the basic generalization that holds across all sets of data is that (i) plural suffixation creates an ill-formed consonant cluster, and (ii) metathesis cannot serve as the repair mechanism in (23)-(30) because, in each of these cases, it would result in the creation of a different ill-formed consonant sequence. Thus, vowel epenthesis functions as an alternate strategy to repair these cluster violations. Another potential repair mechanism for illicit consonant clusters, namely consonant deletion, is hardly ever present in the Nivaĉle data. ${ }^{8}$ The examination of noun plural forms in this section suggests that the constraint MAX-IO (no deletion) is highly ranked in this language, sometimes at the expense of consistency in the linear sequencing of

[e] [i] alternation has been observed by Stell (1987) to be an instance of dialectal variation between the chishamnee (Upriver) and shichaam lhavos (Downriver) speakers. However, the alternation between the two epenthetic vowels [i] [e] also occurs within the shichaam lhavos variety and even within the same speaker. In this regard, it is worth mentioning that the default epenthetic vowel in Spanish is [e].

${ }^{8}$ There is a restricted case of $[\mathrm{x}]$ coda deletion in the context of plural suffixation: for example, utex 'stone', ute-s 'stones'; ji-fxux 'my toe' ji-fxus 'my toes'; see (1), (19) and (20). 
segments (LINEARITY-IO) and sometimes at the expense of introducing vowels that are not part of the input representation (DEP-IO-V).

The data examined here have also shown an essential interplay between the phonological processes of metathesis and epenthesis in relation to well-formedness constraints on syllable structure. ${ }^{9}$ The next sections will elaborate more fully on the roles that prosodic constraints on cluster sequences play vis-à-vis the segmental phonological system of Nivaĉle.

\section{DRIVING FORCES BEHIND METATHESIS AND VOWEL EPENTHESIS}

In this section, the driving forces behind the metathesis (section 3.2) and vowel epenthesis (section 3.3) processes in Nivacte are presented through the analysis of two types of affixation processes: nominal pluralization, and derivation. The major hypothesis advanced in this article is that metathesis is a phonological process motivated by syllable structure constraints, namely, the avoidance of marked structures in the language: complex codas in some cases (section 3.2.1) and bad syllable contacts in others (section 3.2.2). Before moving on to my analysis, I briefly consider a previous proposal.

\subsection{A note on a previous analysis}

From a synchronic perspective, the Nivaĉle stem alternations presented in (18)-(22) have been regarded as VC-metathesis (Stell 1987). ${ }^{10}$ From a diachronic perspective, Campbell and Grondona (2007) have argued that historical vowel (and glottal) deletion is involved. The authors apply internal reconstruction to the forms presented in the singular and plural noun examples in (18)-(22) and posit several sound changes in the history of Nivaĉle. In Table 4, which is adapted from Campbell and Grondona's (2007) work, a vowel that is present in the singular form is missing from the related forms in the plural column. The information in the table has been reorganized with headings, and the phonetic symbols $[y][t s][\phi]$ are re-transcribed as [j], [ts] , and [f].

Following the above morpheme parsing, Campbell and Grondona assume that the Nivaĉle roots underwent "a change which deleted a vowel when a vowel-initial suffix was added" (2007: 6); this change did not affect the singular suffixless

\footnotetext{
${ }^{9}$ Similarly, Hannahs $(2009,2011)$ shows that epenthesis, deletion and metathesis in Welsh illustrate a case of unity within diversity. All of these phonological processes seem to be connected because they serve to avoid a sonority sequencing violation in final consonant clusters (a consonant followed by [n], [r] or [1]), while preserving foot binarity and prosodic minimality. Specifically, Hannahs argues that epenthesis in Welsh occurs with monosyllabic input forms, while deletion and metathesis occur with disyllabic input forms.

${ }^{10} \mathrm{My}$ current analysis of metathesis is very much indebted to Stell's pioneering work on this language. According to Stell (1987), the last vowel of the stem metathesizes with the last consonant of the stem in order to avoid inadmissible consonantal clusters; she provides a very valuable data set of alternating forms. However, no explicit discussion or explanation of the phonetic or phonological motivations behind such a process is considered.
} 


\begin{tabular}{llll}
\hline \hline singular & english gloss & plural & english gloss \\
\hline 1. axutsax & 'hawk' & axutsx-as & 'hawks' \\
2. fatsux & 'centipede' & fatsx-us & 'centipedes' \\
3. snomax & 'ash' & snomx-as & 'ashes' \\
4. kasex & 'seed' & tasx-ej & 'seeds' \\
5. kutsxanax & 'thief' & kutsxanx-as & 'thieves' \\
6. klutsex & 'bow' & klutsx-es & 'bows' \\
7. xump'uwałex & 'mountain lion' & xump'uwałx-es & 'mountain lions' \\
8. paset & 'lip' & past-es & 'lips' \\
9. nas-uk & 'guayacan tree' & nas-k-uj & 'guayacan trees' \\
\hline \hline
\end{tabular}

Table 4: Vowel-alternation examples (adapted from Campbell and Grondona 2007: 5)

words. A reconstruction is then postulated through the following vowel deletion sound change:

$$
\begin{aligned}
& \text { V-deletion } \mathbf{V}>\boldsymbol{\varnothing} / \mathrm{VC} \_\mathrm{C}+\mathrm{V} \\
& \text { *axutsax-as *paset-es } \\
& \text { V-deletion: axutsx-as past-es }
\end{aligned}
$$

However, it is not very clear why this vowel deletion rule occurs in the presence of a "vowel-initial suffix". On the one hand, a double-sided open syllable is a common environment for syncope; on the other hand, if syncope is what is involved here, there is no reason to expect the vowel of the root and the initial vowel of the suffix to have been identical, unless a historically prior vowel harmony process was involved (section 5). However, the authors neither propose nor discuss potential vowel harmony in Nivaĉle. ${ }^{11}$

Further, the $\mathrm{VC} \sim \mathrm{CV}-\mathrm{C}$ alternation, which I analyze as a metathesis process, is not restricted to the plural suffixation pattern that Campbell and Grondona analyze. As will be shown in section 3.3, there are sets of data in which a range of sonorantinitial derivational suffixes trigger the same VC-metathesis. Therefore, not only plural suffixes but also derivational suffixes would need to contain vowels identical to the ones that are deleted in the final syllable of the root. This is an inelegant analysis, because it proposes several allomorphs. The proposal advanced here argues that all these observed data receive a more coherent and integrated interpretation under a prosodic analysis of syllable structure constraints.

\footnotetext{
${ }^{11}$ Even though Campbell and Grondona (2007) do not explicitly mention this implication, under their analysis one would expect the existence of separate plural suffixes for the examples in Table 4: -es, -as, -us, -ej, - $u j$. The suffix allomorph chosen for a given root/stem would be required to have a vowel that matches the root vowel that is targeted by the postulated syncope processes. The way vowel deletion is presented seems to rely on a fortuitous featural identity between the vowels of the root and suffix. "Copy-vowel epenthesis"-that is, epenthesis of a vowel that has the same vowel quality of a nearby vowel (Kitto and de Lacy 1999, Kawahara 2007) - could be invoked as a possible cause.
} 


\subsection{Metathesis}

The following sections consider the motivations for, and an analysis of, the repair of impossible consonant sequences by metathesis.

\subsubsection{Against complex codas}

As noted in section 2, complex codas are not licit syllable types in Nivaĉle, and plural suffixation on C-final nouns would therefore create an illicit CC coda cluster. The proposal advanced here is that metathesis functions as a repair strategy, avoiding a *ComplexCoda violation while preserving the segmental identity of the vocalic and consonantal segments in the input. Further, as observed earlier, the manifestation of an underlying glottal stop as creakiness in the preceding vowel is lost, as shown in (20) above and (33) below, and spirantization of the velar stop may occur, as in (34).

(33) a. /jija?x/

[jijáx]

'puma'

b. /jija?x $+\mathrm{s} /$

[jij.xá-s]

*ji.jáx-s

puma-PL

'pumas'

*jij.xás

(34) a. to.wák

'river'

b. tow.xá-j *to.wák-j

river-PL

'rivers'

Based on the two observations above - namely, that there are no complex codas in Nivaĉle and that there is a change in the linear order of the final vowel and consonant of the root - the following basic constraints are proposed, along with the ranking in (37):

(35) Linearity-IO: No metathesis (McCarthy and Prince 1995:123)

' $\mathrm{S} 1$ is consistent with the precedence structure of S2, and vice versa'

(36) *ComplexCoda: Codas are simple $\left.\left({ }^{*} \mathrm{CC}\right]_{\sigma}\right)$ (Kager 1999)

(37) $* \mathrm{CC}]_{\sigma} »$ LINEARITY-IO

The following tableau shows how the ranking in (37) gives the correct output form for finxas 'crabs.'

\begin{tabular}{|lc||c|c|}
\hline \multicolumn{2}{|c|}{$/$ finax + s/ } & $*$ CC $]_{\sigma}$ & LINEARITY-IO \\
\hline a. $\quad$ fi.naxs & $* !$ & \\
\hline b. $\sigma \quad$ fin.xa-s & & $*$ \\
\hline
\end{tabular}

Under the hypothesis that in the grammar of Nivaĉle it is preferable to violate LinEARITY than CompleXCodA, (38b) emerges as the optimal candidate. 


\subsubsection{Syllable Contact Law}

The examination of derivational suffixes shows that constraints (35) and (36) are not sufficient to explain metathesis. A range of sonorant-initial derivational suffixes trigger the same VC-metathesis phenomenon in a preceding root/stem with a final obstruent, as seen in the following examples.

(39) a. ji-ká.ji

1.Poss-neck

'my front side'

b. ji-kàj.ji-núk

1.Poss-neck-knot

*ji-kaji $\int-n u k$

'my necklace'

(40) a. sa.múk

'excrement'

b. sàm.ku-mát

excrement-VBLz(MALEF)

*samuk-mát

'to evacuate with difficulties'

c. sàm.ku-wát

excrement-LOC

'latrine'

(41) a. fi.n-ák

suck-NOM(RES)

'tobacco'

b. finn-ka-mét

suck-NOM(RES)-shaman/expert

*fin-ak-met $\widehat{\text { J }}$

'shaman that has power over the tobacco'

c. fìn-ka-náx

*fin-ak-náx

suck-NOM(RES)-NMLZ(AG)

'smoker'

(42) a. ka.ț'éx

'diarrhea'

b. kấts.xe-náx

diarrhea-NMLZ(AG)

*samuk-wát

'person that has diarrhea'

(43) a. fe.tét

'bowl'

b. fè̀.țe-jí

bowl-NOM(AR)

'uterus'

(44) a. Ø-wa.k̂êêt

3.s-walk

's/he walks'

b. Ø-wàk. $\widehat{t}$ e-ján

*wakle ț $\int$-ján

3.s-walk-CAus

's/he makes somebody walk'

*fełet $\widehat{\int}-\mathbf{j} \hat{1} \int$ 
(45) a. na.mát 'axe'

b. nàm.ța-wáf axe-mark 'mark/trace of an axe'

*namaț-wás

Here VC-metathesis is not functioning as a repair strategy to avoid a *ComplexCoda violation, which suggests that a different prosodic markedness constraint - one which optimizes the relative sonority of consonants across a syllable coda-onset sequence - is at play.

In contrast, even though sonorant-final stems are rare, the examples in (46)-(48) show licit sonorant-sonorant sequences across morphemic boundaries.

(46) a. t'-ak.fij

3Poss-shoe

'his/her shoe'

b. t'-àk.fij-wáf

3Poss-shoe-mark

'his/her footprints'

c. t'ak-fij[í]s

3POSS-shoe-PL

'his/her shoes'

*t'-ak.fij[i]-wáf

*t'-ak.fji-wáf

*t'ak.fijs

*t'ak.fjis

(47) a. t'a-xuj

3s-go.forward

'she/he goes forward'

b. t'a-xuj-jí

3POSS-go.forward-NMLZ(AR)

'his/her/its front part'

(48) a. j-ej

1s-name

'my name'

b. j-ej-ján

3s-name-CAUS

'they name (him/her)' *t'a-xu.j[i]-jíf

*t'ax.ju.jí

*j-ej[íljan

There is no metathesis or epenthesis when the syllable contact does not involve an Obstruent-Sonorant contact across a morpheme boundary, as opposed to the data illustrated in (39)-(45), which do show metathesis. In these cases, suffixes with an initial sonorant - specifically, /m/, /n/, /j/ and /w/ - are attached to an obstruentfinal stem. Rather than the expected linear concatenation (e.g., *fin-ak-met $\widetilde{j})$ the final obstruent of the stem metathesizes with the preceding vowel: fin-ka-mét $\int$. Schematically, where $\mathrm{O}$ stands for an Obstruent and S stands for a Sonorant, the linear segmental sequence is reordered as follows: $* \mathrm{~V}_{1} \mathrm{O}-\mathrm{SV} \rightarrow \mathrm{OV}_{1}-\mathrm{SV}$. Moreover, metathesis results in a new coda-onset sequence inside of the stem, [n.k], but this S.O cluster does not exhibit bad syllable contact. In the analysis that follows, I argue that there is a constraint against an obstruent-sonorant coda-onset sequence (i.e., *O.S). In these cases, metathesis functions as a strategy to repair what would otherwise be a prosodically non-optimal sequence. 
Specifically, I argue that the driving force behind this second type of metathesis is the Syllable Contact Law (SCL) proposed by Murray and Vennemann (1983) and Vennemann (1988) in order to explain syllabification patterns and sound change at syllable boundaries. Basically, the consonantal strength of the coda should exceed or be equal to the consonantal strength of the following onset. Vennemann (1988: 8) defines consonantal strength as "a phonetic parameter of [...] unimpeded (voiced) airflow" and proposes that sounds are organized in a universal ordering known as the Consonantal Strength Hierarchy, tracing back to Sievers (1881) and Brugmann (1897).

Some discussions of the SCL (Parker 2002, 2012; Gouskova 2004) have replaced consonantal strength with sonority, a concept that has been widely invoked as an explanatory principle in several different types of phonological analyses, but that also has been the object of extensive debate and controversy. A number of cross-linguistic tendencies with respect to the distribution and sequencing of segments have been made with reference to sonority hierarchies. When major natural classes are considered, the generalized sonority hierarchy in (49) is commonly assumed.

(49) Vowels $>$ Glides $>$ Liquids $>$ Nasals $>$ Obstruents

(Clements 1990, Kenstowicz 1994)

Only if the Syllable Contact Law is interpreted in terms of the Sonority Hierarchy in (49) do the data in (39)-(45) show cases where the concatenation of morphemes results in bad syllable contact. Specifically, suffixation creates an obstruent-sonorant heterosyllabic sequence, where the sonority of an obstruent coda is lower than the sonority of a following onset. I thus hypothesize that (i) this type of sonority reversals like this are not tolerated in Nivaĉle, and (ii) metathesis functions as a repair strategy that optimizes an otherwise illicit syllable transition. As a result, a vowel-sonorant transition emerges at the site of morpheme concatenation, thus optimizing Syllable Contact. Note at the same time that the (underlying) stem-final obstruent is shifted by metathesis into an Onset position; for example, the stemfinal [k] of (41), *fin-ak-met $\widehat{\int} \rightarrow$ fin-ka-mét $\int$, now surfaces as an Onset rather than a Coda (and the [n.k] sequence does not violate the Syllable Contact Law). As a result, $\mathrm{CV}$ obstruent-vowel transitions are created. Because the most reliable perceptual cues to place of articulation in a stop depend on the formant transitions into a vowel, VC-metathesis also optimizes the perception of non-continuant obstruents.

On the basis of my Nivaĉle data, I assume the following sonority scale, where adjacent categories of Glides-Nasals and Fricatives-Affricates-Stops are conflated into the single categories of Sonorant and Obstruent, respectively.

(50) Vowels $>$ Sonorants $>$ Obstruents

In an Optimality Theoretic analysis, the Syllable Contact Law represents a family of constraints, which can be instantiated for Nivaĉle in the following terms:

(51) SYLLABLE CONTACT LAW (SCL) $\left.\left({ }^{*[-s o n]}\right]_{\sigma} \sigma^{[+ \text {son }]}\right)$ : Sonority should not rise across a syllable boundary (from an obstruent to a sonorant).

The interaction between the SCL constraint and the previously proposed LINEARITYIO constraint is illustrated in the following tableau. I defer the discussion of another potential candidate, $*$ [fi.na.ki.met $\left.\int\right]$, which involves epenthesis, until section 3.3. 
(52) SCL, *ComplexCoda » Linearity-IO

\begin{tabular}{|c|c|c|c|}
\hline /finak+met $\bar{f} /$ & $\mathrm{SCL} *[-$ son $]]_{\sigma \sigma}\left[{ }^{[+ \text {son }}\right]$ & ${ }^{*}$ COMPLEXCODA & LINEARITY-IO \\
\hline a. fi.nak.met $\widehat{\int}$ & $* ![\ldots$ k.m ...] & & \\
\hline b. $\sigma$ fin.ka.met $\widehat{\jmath}$ & & & * \\
\hline c. fi.na.kem $\widehat{t}$ & & $* !$ & ** \\
\hline
\end{tabular}

The most faithful candidate to the input, (a), fatally violates SCL and is thus discarded. Candidate (b) surfaces as the optimal output because it violates the lower ranked LINEARITY-IO once, whereas (c) violates *COMPLEXCODA and LINEARITY-IO twice.

In essence, the hypothesis I am proposing is that syllable contact markedness constraints are highly ranked in Nivaĉle and will trigger metathesis, a LiNEARITYIO violation. Under this proposed analysis, an interesting question arises: What happens if suffixation of a sonorant-initial suffix to an obstruent-final stem should trigger metathesis in order to avoid violating the SCL, but the linear reordering of the final vowel and consonant of the root would itself incur a violation of a higher ranked constraint (for instance, *COMPLEXCODA)? In these cases, vowel epenthesis takes place, an issue I discuss in the following section.

\subsection{Vowel epenthesis}

When the linear reordering (metathesis) of the final vowel and consonant of a stem would incur a violation of a higher ranked constraint, epenthesis emerges as a repair mechanism. In (54) below, for example, if metathesis were applied to avoid a bad syllable contact [...k-w...] (54a), a complex (and illicit) onset [p'k] would result (54b). ${ }^{12}$ Complex onsets do exist word-initially, but they never arise as the result of metathesis or another syllable repair mechanism. Further, deletion of the final consonant is not observed as an alternative strategy (54c). Faithfulness to consonantal identity of lexical representation is highly ranked in the Nivaĉle grammar. Finally, (54d) shows that metathesis cannot occur across morpheme boundaries.

$$
\begin{array}{ll}
\multicolumn{2}{l}{\text { /p'ok/ 'arrow'+/-waj/ 'mark' }} \\
\text { a. *p'ok-wa } & \text { SCL } \\
\text { b. *p'ko-wa } & { }_{\sigma} \mathrm{CC} \\
\text { c. *p'o-wa } & \text { MAX- SEG } \\
\text { d. *p'ow-ka } & \text { LinEARITY-IO } \\
\text { e. *p'ok-[i]wa } \checkmark & \text { Dep-IO-V }
\end{array}
$$

Since the first rescue strategy - metathesis within the first morpheme, as in (54b) - does not result in an acceptable syllabic parse, the best repair strategy in this case is vowel epenthesis, a DEP-IO-V violation (54e). In tableau (59) we can see the relative ranking of DEP-IO-V and MAX-SEG, and metathesis and epenthesis jointly "conspiring" (Kisseberth 1970) to eliminate bad syllable contact sequences, namely, SCL

\footnotetext{
${ }^{12}$ Candidate (54b) is also ruled out by a laryngeal constraint whereby ejectives do not occur before consonants.
} 
violations. *ComplexOnset and *ComplexCoda are the conditioning factors that give rise to the variation between one process and the other. The ranking in (58) crucially establishes that MAX-SEG is higher ranked than DeP-IO-V: vowel epenthesis is a better repair strategy than deletion of the final consonant of the stem. In contrast, the relative ranking of DEP-IO-V with regards to $\left[{ }_{\sigma} \mathrm{CC}\right.$ is not clear, given that complex onsets do occur (word-initially) in Nivaĉle.

(55) *ComplexOnSET: Onsets are simple $\left(*{ }_{\sigma} \mathrm{CC}\right)$

(Kager 1999)

(56) MAX- SEG: Input segments have output correspondents ('No deletion').

(Kager 1999)

(57) Dep-IO-V: Every vowel in the output has a correspondent in the input.

(Kager 1999)

(58) SCL, MAX-SEG » DeP-IO-V, *[б $\mathrm{CC} \gg$ LINEARITY-IO

\begin{tabular}{|c|c|c|c|c|c|}
\hline /p'ok-waj/ & $\left.\mathrm{SCL}^{*[- \text { son }]}\right]_{\sigma \sigma}\left[{ }^{[+ \text {son }]}\right.$ & MAX-SEG & DEP-IO-V & $*\left[{ }_{\sigma} \mathrm{CC}\right.$ & LIN-IO \\
\hline a. p'ok-wa & $* !$ & & & & \\
\hline b. p'ko-wa & & & & * & $* !$ \\
\hline c. p'o-wa & & $* !$ & & & \\
\hline d. $\sigma^{\prime}$ 'ok-[i]wa & & & * & & \\
\hline
\end{tabular}

While candidates (59a) and (59c) get discarded because they violate SCL and MAX-SEG, an interesting contrast can be seen between (59b) and (59d). Each candidate incurs one violation from the crucially unranked constraints $*_{\sigma}\left[\mathrm{CC}\right.$ and DEP-IO-V. ${ }^{13}$ Importantly, candidate (59b) also incurs one violation of LINEARITY-IO, so candidate (59d) emerges as the optimal output. In sum, whenever possible, metathesis is applied to avoid a bad syllable contact. If metathesis creates an illicit consonant cluster, vowel epenthesis is applied.

Vowel epenthesis is also observed when C-initial plural allomorphs are attached to stems with a medial cluster. In these cases, DEP-IO-V must be also crucially outranked by an undominated syllable markedness constraint, namely *CoMPLEXCODA. As mentioned above, it was already established that while complex onsets occur in Nivaĉle, they never emerge as a result of metathesis; ${ }^{*}{ }_{\sigma} \mathrm{CC}$ is crucially unranked with respect to DEP-IO-V, and they are both ranked higher than LINEARITY-IO. The emergence of complex codas and complex onsets is thus avoided through vowel epenthesis. Let us consider the following example:

\footnotetext{
${ }^{13}$ Note that there are two interpretations of crucial non-ranking/crucially unranked constraints: (i) crucial non-ranking (Antilla 1997), which produces variation, and (ii) coranking/equal ranking, where both constraints are evaluated simultaneously and it is crucial that $\mathrm{C} 1$ and $\mathrm{C} 2$ are located in the same position in the ranking (Crowhurst 2001, Crowhurst and Michael 2005, Topintzi 2005, among others). I use it here in this second sense.
} 
(60) a. Tึin.t]e éx

'spirit'

b. T⿱tìn. $\widehat{t} \int \mathrm{e} \cdot \mathrm{x}-[1] \mathrm{s}$

spirit-PL

'spirits'

c. * t]in.t]ex-s

d. * $\overparen{t}$ in. $\overparen{t} \mathrm{xe}-\mathrm{s}$

e. * $\widetilde{\mathrm{t}}$ int $\int . x e-s$

f. * $\widetilde{t}$ in. $\widetilde{t}$ e-s

As in the example discussed in (54), metathesis does not occur in (60) because it would either result in a derived complex onset (60d) or a complex coda (60e). Deletion of the final consonant of the stem, as a strategy to avoid the emergence of a complex coda in (60f), is also not permitted. Consider the candidates in (60) in the following tableau (62), along with the following proposed ranking of constraints (61):

$* \mathrm{CC}]_{\sigma}, \mathrm{MAX}-\mathrm{Seg} \gg \mathrm{DEP}-\mathrm{IO}-\mathrm{V}, *{ }_{\sigma} \mathrm{CC} \gg$ Linearity-IO

(62)

\begin{tabular}{|c|c|c|c|c|c|}
\hline /tfintfe? $\mathrm{x}+\mathrm{s} /$ & $\left.{ }^{*} \mathrm{CC}\right]_{\sigma}$ & MAX-SEG & $\begin{array}{l}\text { DEP-IO- } \\
\mathrm{V}\end{array}$ & $*\left[{ }_{0} \mathrm{CC}\right.$ & LINEARITY-IO \\
\hline a. $\quad \widehat{t} \int \mathrm{in} . \overline{\mathrm{t} f} \mathrm{ex}-\mathrm{s}$ & $* !$ & & & & \\
\hline b. $\widehat{\text { tf }}$ in. $\widehat{t} \int \mathrm{xe}-\mathrm{s}$ & & & & $*$ & $* !$ \\
\hline c. $\widehat{\text { t }}$ int $\widehat{\int} \cdot x e-s$ & $* !$ & & & & $*$ \\
\hline 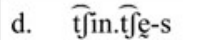 & & $* !$ & & & \\
\hline e. $\sigma \widehat{t}$ fin.t $\widehat{t} \operatorname{ex}[\mathrm{i}]-\mathrm{s}$ & & & $*$ & & \\
\hline
\end{tabular}

Candidate (62e) emerges as the optimal output: vowel epenthesis is the best strategy to avoid the emergence of a complex coda (62a, 62c), or a complex onset due to metathesis $(62 \mathrm{~b})$ when the root has a medial CC cluster / $\overparen{\mathrm{t}} \mathrm{int} \widehat{\mathrm{f}} \mathrm{e} \mathrm{x} /$ (as opposed to a medial singleton $\mathrm{C}$ as in /finax/). Deletion of a segment is worse than epenthesizing a vowel, so candidate $(62 \mathrm{~d})$ gets discarded.

\section{Domain OF METATHESIS}

It is often the case in languages where metathesis is driven by the Syllable Contact Law that the consonants across a syllable or morpheme boundary are the ones that metathesize. For instance, we find in Sidamo (Gouskova 2004: 228-229): /habnemmo/ $\rightarrow$ [han-bemmo] 'we forget'; /has-nemmo/ $\rightarrow$ [han.semmo] 'we look for'; in Old Spanish (Holt 2004: 52) /kad.nado/ $\rightarrow$ [kan.dado] 'lock'; and in Leti (van Engelenhoven 2004: 91): lau 'civet' + nama 'tongue' $\rightarrow$ [lanwama]. However, in Nivaĉle, the ill-formed *O-S consonant sequence across the root-suffix boundary (63b) does not metathesize. Rather, metathesis in Nivaĉle is root-bound; it affects the final consonant of the root and the preceding vowel (63a).

(63) $\quad /$ fełet $\widehat{\jmath}+\mathrm{ji} / /$
a. $\checkmark$ fed.ţe-jif 'uterus'
b. * fe.tej- $\widehat{-t} \mathrm{i}$ j 
In other words, although the trigger for metathesis is the fact that the initial consonant of the suffix is more sonorous than the final consonant of the root, the repair mechanism for this violation of the Syllable Contact Law does not involve segments from two different morphological domains (63b). On the contrary, the segments that metathesize are exclusively within the morphological domain of the root; Nivaĉle metathesis respects morpheme boundaries. For purposes of clarity, the examples in (63) are repeated in (64); the right edge of the root is indicated, and the ordering reversals of candidates (64a) and (64b) are marked with crossing lines.

$$
\text { a. Input: } \quad \text { /f e } 1 \text { e } \widehat{\left.\mathrm{t}^{\top}\right]_{R}-\mathrm{j} \text { i } \mathrm{f} /}
$$

b.

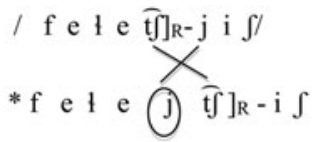

As indicated by the circled segment in (64b), if metathesis were to reverse the order of the final consonant of the root and the initial consonant of the suffix, then the suffix consonant (the circled [j]) would intrude between the contiguous [e] and $[\mathrm{t}]$ ] segments of the root.

In sum, the Nivacle pattern is in line with proposed cross-linguistic tendencies for metathesis. Mielke and Hume (2001) have argued that metathesis disrupts word and root recognition, so ordering reversals tend to involve adjacent segments at the middle or right edge of the root.

\section{METATHESIS AND PSEUDOMETATHESIS}

Having established the broad range of properties that characterize and constrain the VC-metathesis process in Nivaĉle, one of the remaining issues is to consider how this case fits the broader cross-linguistic typology of metathesis.

Under the theoretical umbrella of Evolutionary Phonology (Blevins 2004), historical, non-teleological, and phonetic explanations are posited for synchronic sound patterns. Blevins and Garrett (2004) propose four categories of phonetically natural metathesis processes (examples are taken from their article): (i) perceptual metathesis: features with elongated phonetic cues are reinterpreted in non-historic positions (e.g., laryngeal metathesis in Cayuga); (ii) compensatory metathesis: within a foot, a feature in a weak syllable shifts to a strong syllable (e.g., $\hat{V}_{1} C_{2} \rightarrow \dot{V}_{1} V_{2} C$ in Rotuman); (iii) coarticulatory metathesis: the overlap in gestures of two adjacent segments - that is, CC coarticulation - results in a reinterpreted ordering (e.g., Mokilese $\mathrm{kp} \rightarrow \mathrm{pk}$ ); and (iv) auditory metathesis: the sibilant noise present in a sequential speech stream is decoupled from the speech stream (e.g., sibilant-stop, stop-sibilant metatheses).

Importantly, Blevins and Garrett state that other synchronic alternations, such as $\mathrm{VC}>\mathrm{CV}$ or $\mathrm{CV}>\mathrm{VC}$-metathesis that lack the phonetically natural properties listed in the above typology, are actually cases of pseudometathesis (Mills and Grima 1980). More precisely, what looks on the surface like synchronic CV- or VC-metathesis may actually involve two processes (also known as telescoping (Wang 1968)): 
copy-vowel epenthesis and historical vowel deletion. The challenge posed by pseudometathesis processes is that the two discrete processes might not be independently recoverable and are therefore opaque.

The Nivache VC/CV synchronic alternations motivated by prosodic constraints do not fall into any of the metathesis categories proposed by Blevins and Garrett (2004). Therefore, two options could be considered. One is that these alternations are a case of pseudometathesis. The other is that the Nivaĉle data argue for an additional category in the cross-linguistic typology.

Under the first hypothesis, namely that the Nivaĉle data are best interpreted as a case of pseudometathesis, two diachronic processes could be posited: (i) epenthesis of a copy-vowel into an otherwise illicit syllable structure, and (ii) deletion/syncope of the underlying vowel of the stem that served as the base for the copy-vowel epenthesis process, as demonstrated in (65).

(65) "Stage I":

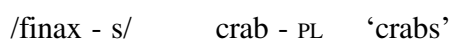

As a more fully fleshed-out version of Campbell and Grondona's (2007) proposal, this approach would have the advantage of reducing the number of suffix allomorphs in both the inflectional and derivational domains. Instead of a multiplicity of vowel-initial allomorphs that are required to match the preceding vowel in the stem (e.g., -is, -es, -as, -as, -os, -us, -ij, -ej, aj, etc.), the lexical identity of the allomorphs would be simply consonantal (i.e, $-s,-j,-\widehat{k l}$ ). ${ }^{14}$

Some evidence for copy-vowel epenthesis can be seen in (66)-(69) (also presented in section 2.1.4). In these examples, suffixation of the plural allomorph $-j$ to a consonant-final stem with a glottalized vowel involves a harmonic epenthetic vowel:
a. /afte?k1/
[?aftéck ]
'orphan'
b. àftek̂-[é]j
orphan-PL
'orphans'
(67) a. $/ \mathrm{xo}$ ?t/
[xót]
'sand'
b. xot-[ó]j
sand-PL
'sandy lands'

\footnotetext{
${ }^{14}$ Alternatively, as a reviewer points out, it could be posited that the plural allomorphs have vowels with unspecified features $(-\mathrm{Vs},-\mathrm{Vj},-\mathrm{V} \widehat{\mathrm{kl}})$ and there is a rule that copies the features of the vowel in the base.
} 


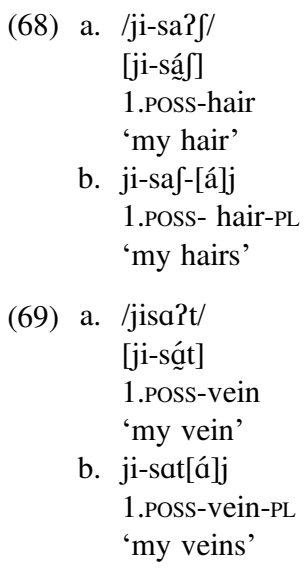

In (66)-(69), vowel syncope (or metathesis) does not occur, because it would yield an illicit consonant cluster: either a complex coda or a word-medial complex onset in aft.klej/ af.tklej (66), an unattested (and derived) complex onset cluster $x t$ (67), or a medial cluster $s . f(68)$. It is not clear, though, why *[jistaj] is not an optimal output for (69). I can only hypothesize at this point that [s] was in fact, at some stage, in variation with [t] ], as originally observed by Hunt (1924).

In sum, pseudometathesis (copy-vowel epenthesis and vowel syncope), could explain the Nivaĉle alternating form phenomena that are here analyzed as synchronic metathesis. However, this approach is problematic in at least one respect. As discussed in section 2.1.4, the most regular Nivaĉle epenthetic vowel is [i]. What would be the motivation, then, for a subset of nouns to undergo harmonic vowel epenthesis while another, larger set adopts [i]-epenthesis? While all the forms listed above have glottalized vowels, it is also true that [i]epenthesis also applies to roots with glottalized vowels (e.g., klóp 'winter', klopís 'winters'). This is still a puzzling topic; I have not yet reached an adequate explanation.

With regards to vowel syncope, which is neither a regular process nor as productive as vowel epenthesis, it sometimes involves vowel identity between the vowel of the stem and the suffix, as in (70)-(71), but other times does not, as in (72)-(73):

(70) Syncope of $[e]$ before $[e]$
a. nißak̂é 'man'
b. nißak-ţé
man-F
'woman'

(71) Syncope of $[\mathbf{a}]$ before $[\mathbf{a}]$
a. k̂lòj-xanáx
dance-AG
'dancer' 


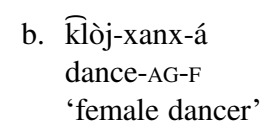

(72) Syncope of $[\mathbf{a}]$ before $[\mathbf{i}]$
a. j-ofád
3.s-burst
'it bursts'
b. j-oft-ít
3.s-burst-CAUS
's/he breaks'

(73) Syncope of [i] before epenthetic [a]
a. nají
'road'
b. naj $[$ á]j
road-PL
'roads'

The fact that vowel deletion, [?] deletion, and both harmonic and non-harmonic vowel epenthesis are attested in Nivaĉle points to the range of phonological processes that Nivaĉle stems undergo in the context of suffixation. Two challenges thus seem to exist for the pseudometathesis account: (i) the existence of non-harmonic vowel epenthesis, and (ii) the fact that [i]-epenthesis and "copy-vowel epenthesis + syncope" (i.e., synchronic metathesis) seem to be in a principled, complementary distribution. ${ }^{15}$ More specifically, if epenthesis were a historically earlier change than syncope, why would epenthesis have involved a copy- $\mathrm{V}$ in exactly those environments that would later be subject to syncope, and a non-copy-vowel [i] in those environments where, it turned out, the eventual syncope would not happen? In any case, the possibility that VC-metathesis arose through the reanalysis of what originated diachronically as copy-vowel epenthesis and (unstressed) vowel syncope sound changes definitely needs to be further explored within Nivaĉle and across the Mataguayan languages.

Whatever its historical origin, I propose that synchronic VC-metathesis functions as a phonological strategy to avoid violation of syllable structure constraints and to optimize the sonority cline of heterosyllabic consonant clusters. As Crowhurst and Trechter (2014:148) point out in their analysis of vowel-rhotic metathesis in Guarayu, phonological factors may contribute to the diffusion and the generalization of metathesis as the innovative pattern. Moreover, the elimination of complex codas and bad syllable contacts is structure-preserving: neither complex codas nor obstruent-sonorant sequences are ever attested as well-formed structures in the Nivaĉle language. What is more, the correlation between metathesis and structure preservation has been suggested by Hume (2004: 221): “any order of two segments is a potential

\footnotetext{
${ }^{15}$ One of the reviewers suggests that i-epenthesis could have emerged at a later stage than copy-vowel epenthesis and replaced it. I cannot confirm this possibility due to the lack of historical documents.
} 
output of metathesis, provided that the reordered sequence forms an attested structure in the language". I argue that what I analyze as synchronic VC-metathesis in Nivaĉle thus conforms to a model that is different in its perspective from Evolutionary Phonology. Furthermore, I have observed in the context of the proposed analysis that VC-metathesis is blocked when the output of metathesis would incur violations of high-ranked syllable markedness constraints such as *COMPLEXCODA; instead, vowel epenthesis occurs. Metathesis and vowel epenthesis can be regarded as two conspiring mechanisms driven by the avoidance of marked structures. A detailed analysis of the interrelation between vowel deletion, epenthesis and metathesis in Nivaĉle, and within the Mataguayan family, constitutes an issue for future investigation.

\section{Conclusions}

In this article, I have provided an Optimality Theory account for vowel-consonant metathesis in Nivaĉle, which takes place in the presence of some inflectional and derivational affixation processes such as pluralization of nouns and nominal/verbal derivation. I have also showed that a previous analysis of the stem alternations in this language - namely, historical vowel deletion (Campbell and Grondona 2007) does not account for a wider range of data.

Here I have argued that there are two distinct motivations behind vowel-consonant metathesis in Nivaĉle. One type of metathesis is motivated by the avoidance of illicit syllable structures: complex codas are never allowed in Nivaĉle. The other source of metathesis is the optimization of the sonority contact in coda-onset sequences. Both types of constraints constitute well-attested cross-linguistic tendencies to avoid (i) complex syllable margins and (ii) rising sonority values across syllable edges. $\left.{ }^{*} \mathrm{CC}\right]_{\sigma}$ and the Syllable Contact Law, in interaction with LiNEARITY-IO, successfully captured the two generalization patterns.

In addition, only segments within the root can metathesize: that is, elements from other domains (i.e., the suffix) cannot intrude into the root. These patterns from Nivaĉle confirm the cross-linguistic tendencies for metathesis discussed in Hume (2004): (i) metathesis involves adjacent segments, and (ii) ordering reversals are preferred at the end of stems and words, because word position and proximity constitute significant factors for speech processing (Mielke and Hume 2001).

Furthermore, I have shown that when the linear reordering of the final vowel and consonant of a stem would incur a violation of a higher ranked constraint, vowel epenthesis emerges as a repair mechanism. In other words, vowel epenthesis occurs when VC-metathesis would yield illicit consonant clusters. These two processes thus seem to be in complementary distribution and jointly conspire to eliminate bad syllable contact sequences.

Finally, I have briefly discussed the plausibility of the pseudometathesis account for the history of metathesis in Nivaĉle. Under this view, two diachronic processes must be posited: copy-vowel epenthesis and vowel syncope. The lack of historical documentation on the Nivaĉle language makes it difficult and speculative to ascertain 
whether there was ever copy-vowel epenthesis followed by syncope at a later stage. Nevertheless, from a synchronic perspective, I have shown that VC-metathesis is motivated by phonotactics in Nivaĉle.

\section{REFERENCES}

Antilla, Arto. 1997. Deriving variation from grammar: A study of Finnish genitives. In Variation, change and phonological theory, ed. Frans L. Hinskens, Roeland van Hout, and Leo Wetzels, 35-68. Amsterdam: John Benjamins.

Blevins, Juliette. 2004. Evolutionary phonology: The emergence of sound patterns. Cambridge: Cambridge University Press.

Blevins, Juliette, and Andrew Garrett. 1998. The origins of consonant-vowel metathesis. Language 74(3): 508-556.

Blevins, Juliette, and Andrew Garrett. 2004. The evolution of metathesis. In Phoneticallybased phonology, ed. Bruce Hayes, Robert Kirchner, and Donca Steriade, 117-156. Cambridge: Cambridge University Press.

Brugmann, Karl. 1897. Einleitung und Lautlehre [Introduction and phonology]. Vol.1 of Grundriss der vergleichenden grammatik der Indogermanischen sprachen [Elements of the comparative grammar of the Indo-Germanic languages]. Second edition. Straßburg: Karl Trübner.

Buckley, Eugene. 2007. Vowel-sonorant metathesis in Alsea. International Journal of American Linguistics 73(1): 1-39.

Buckley, Eugene. 2011. Metathesis. In The Blackwell Companion to Phonology, ed. Marc van Oostendorp, Colin J. Ewen, Elizabeth Hume, and Keren Rice, 1380-1407. Malden, MA: Wiley-Blackwell.

Campbell, Lyle, and Verónica Grondona. 2007. Internal reconstruction in Chulupí (Nivaklé). Diachronica 24(1): 1-29.

Claesson, Kenneth. 1994. A phonological outline of mataco-noctenes. International Journal of American Linguistics 60(1): 1-38.

Clements, G. N. 1990. The role of the sonority cycle in core syllabification. In Papers in laboratory phonology I. Between the grammar and physics of speech, ed. John Kingston and Mary Beckman, 283-333. Cambridge: Cambridge University Press.

Coetzee, Andries W. 1999. Metathesis in Tiberian Hebrew: A perspective from Optimality Theory. Theoretical Linguistics 25: 99-131.

Crowhurst, Megan J. 2001. Coda conditions and um infixation in Toba Batak. Lingua 111(8): 561-590.

Crowhurst, Megan J., and Lev Michael. 2005. Iterative footing and prominence-driven stress in Nanti (Kampa). Language 81(1): 47-95.

Crowhurst, Megan J., and Sara Trechter. 2014. Vowel-rhotic metathesis in Guarayu. International Journal of American Linguistics 80(2): 127-173.

Czaplicki, Bartlomiej. 2009. Non-teleological approaches to metathesis: Evidence from dialects of Polish. Poznan Studies in Contemporary Linguistics 45(3): 353-446.

DGEEC. 2012. III Censo Nacional Indígena de Población y Viviendas 2012: Pueblos indígenas del Paraguay [III National indigenous population and housing census: Indigenous peoples of Paraguay]. Asunción: Dirección General de Estadística Encuestas y Censos. <dgeec.gov.py> 
Edwards, O.D.E. 2018. The Morphology and Phonology of Metathesis in Amarasi. Morphology 28(1): 25-69.

van Engelenhoven, Aone. 2004. Leti, a language of Southwest Maluku. Leiden: KITLV Press. Fabre, Alain. 2016. Gramática de la lengua nivacle (familia mataguayo, chaco paraguayo). [Nivacle grammar (Mataguayan family, Paraguayan Chaco)] Muenchen: LINCOM.

Faust, Noam. 2014. Templatic metathesis in Tigre imperatives. Phonology 31 (2): 209-227.

Gerzenstein, Ana. 1983. Lengua chorote. Variedad No 2 [The Chorote language. Variety No 2]. Buenos Aires: Facultad de Filosofía y Letras, Universidad de Buenos Aires.

Gerzenstein, Ana. 1999. Diccionario Etnolinguístico Maká-Español [Ethnolinguistic dictionary Maká-Spanish] (DELME). Buenos Aires: Facultad de Filosofía y Letras, Universidad Nacional de Buenos Aires.

Gutiérrez, Analía. 2015. Segmental and prosodic complexity in Nivaĉle: Laryngeals, laterals, and metathesis. Doctoral dissertation, University of British Columbia, Vancouver.

Gutiérrez, Analía. 2019. A reanalysis of Nivacle $\widehat{\mathrm{kl}}$ and 4: Phonetic, phonological and typological evidence. International Journal of American Linguistics 85(1): 45-74.

Gouskova, Maria. 2004. Relational hierarchies in Optimality Theory: The case of syllable contact. Phonology 21(2): 201-250.

Hannahs, Stephen J. 2009. Welsh svarabhakti: Sonority sequencing and foot structure. Journal of Celtic Linguistics 13(1): 21-44.

Hannahs, Stephen J. 2011. Unity in diversity in Welsh: The avoidance of sonority sequencing violations. In Formal approaches to Celtic linguistics, ed. Andrew Carnie, 259-374. Newcastle upon Tyne: Cambridge Scholars Publishing.

Holt, Eric. 2004. Optimization of syllable contact in Old Spanish via the sporadic sound change metathesis. Probus 16(1): 43-61.

Hooper, Joan B. 1976. An introduction to natural generative phonology. New York: Academic Press.

Hume, Elizabeth. 1991. Metathesis in Maltese: Implications for the strong morphemic plane hypothesis. In Proceedings of the North East Linguistic Society 21, ed. Tim D. Sherer, 157-172. Amherst: GLSA.

Hume, Elizabeth. 1998. Metathesis in phonological theory: The case of Leti. Lingua 104 (3-4), 147-180.

Hume, Elizabeth. 2001. Metathesis: Formal and functional considerations. In Surface syllable structure and segment sequencing, ed. Elizabeth Hume, Norval Smith, and Jeroen van de Weijer, 1-25. Leiden: Holland Institute of Generative Linguistics.

Hume, Elizabeth. 2004. The indeterminacy/attestation model of metathesis. Language, 80(2): 203-237.

Hume, Elizabeth, and Misun Seo. 2004. Metathesis in Faroese and Lithuanian: From speech perception to Optimality Theory. Nordic Journal of Linguistics 27(1): 35-60.

Hunt, Richard. 1924. Chunupi or suhin. Grammar, lessons and vocabulary. Embarcación: Misión Chaqueña.

INDEC. 2004-2005. Encuesta Complementaria de Pueblos Indígenas. Buenos Aires: Instituto Nacional de Estadística y Censos [Complementary survey of indigenous peoples]. <indec. mecon.ar/webcenso/ECPI/index ecpi.asp>

Itô, Junko. 1986. Syllable theory in prosodic phonology. Doctoral dissertation, University of Massachusetts, Amherst.

Itô, Junko, and Armin Mester. 1994. Reflections on CodaCond and Alignment. In Phonology at Santa Cruz, ed. Jason Merchant, Jay Padgett, and Rachel Walker, 27-46. Santa Cruz: University of California, Santa Cruz.

Kager, René. 1999. Optimality Theory. Cambridge: Cambridge University Press. 
Kawahara, Shigeto. 2007. Copying and spreading in phonological theory: Evidence from echo epenthesis. In University of Massachusetts occasional papers in linguistics 32: Papers in Optimality Theory III, ed. Leah Bateman, Michael O'Keefe, Ehren Reilly, and Adam Werle. Amherst: GLSA Publications.

Kenstowicz, Michael. 1994. Phonology in generative grammar. Oxford: Blackwell.

Kitto, Catherine, and Paul de Lacy. 1999. Correspondence and epenthetic quality. In Proceedings of AFLA VI: The sixth meeting of the Austronesian formal linguistics association, ed. Carolyn Smallwood and Catherine Kitto, 181-200. Toronto: University of Toronto.

Kisseberth, Charles W. 1970. On the functional unity of phonological rules. Linguistic Inquiry 1(3): 291-306.

Lombardi, Linda. 1995. Laryngeal neutralization and syllable wellformedness, Natural Language and Linguistic Theory 13: 39-74.

McCarthy, John J. 2000. The prosody of phrase in Rotuman. Natural Language and Linguistic Theory 18: 147-197.

McCarthy, John J., and Alan Prince. 1995. Faithfulness and reduplicative identity. University of Massachusetts Occasional Papers in Linguistics 18: 249-384.

Mielke, Jeffrey, and Elizabeth Hume. 2001. Consequences of word recognition for metathesis. In Surface syllable structure and segment sequencing, ed. Elizabeth Hume, Norval Smith, and Jerome van de Weijer, 135-158. Leiden: Holland Institute of Generative Linguistics.

Mills, Roger F., and John Grima. 1980. Historical developments in Lettinese. In Papers from the second Eastern conference on Austronesian languages, ed. Paz Buenaventura Naylor, 273-284. Ann Arbor: University of Michigan.

Morelli, Frida 1999. The phonotactics and phonology of obstruent clusters in Optimality Theory. Doctoral dissertation, University of Maryland.

Morelli, Frida. 2003. The relative harmony of /s + stop/ onsets: Obstruent clusters and the sonority sequencing principle. In The syllable in Optimality Theory, ed. Caroline Féry and Ruben van de Vijver, 356-371. Cambridge: Cambridge University Press.

Murray, Robert W., and Theo Vennemann. 1983. Sound change and syllable structure: Problems in Germanic phonology. Language 59(3): 514-528.

Najlis, Elena. 1984. Fonología de la protolengua mataguaya [Phonology of the protoMataguayan language]. Buenos Aires: Instituto de Lingüística.

Parker, Steve. 2002. Quantifying the sonority hierarchy. Doctoral dissertation, University of Massachusetts, Amherst.

Parker, Steve, ed. 2012. The sonority controversy. (Phonology and phonetics 18). Berlin and Boston: De Gruyter Mouton.

Prince, Alan, and Paul Smolensky. 2004. Optimality Theory: Constraint interaction in generative grammar. Malden, MA: Blackwell. [1993]

Seelwische, José. 1990. Diccionario nivaclé: nivaclé-castellano, castellano-nivaclé [Nivacle dictionary: Nivacle-Spanish, Spanish-Nivacle]. Mariscal Estigarribia/Asunción: Centro de Estudios Antropológicos de la Universidad Católica.

Shaw, Patricia A. 2009. Inside access: The prosodic role of internal morphological constituency. In The nature of the word: Essays in honor of Paul Kiparsky, ed. Kristin Hanson and Sharon Inkelas, 241-272. Cambridge: Massachusetts Institute of Technology Press.

Stell, Nélida N. 1987. Gramática descriptiva de la lengua niwaklé (chulupí) [Descriptive grammar of the Nivacle language (Chulupí)]. Doctoral dissertation, Universidad de Buenos Aires.

Sievers, Eduard. 1881. Grundzüge der phonetik [Fundamentals of phonetics]. Leipzig: Breitkopf und Hartel. 
Topintzi, Nina. 2005. Putting 'commas' at the right place: A note on crucial non-ranking in OT. UCL Working Papers in Linguistics 17: 83-108.

Vennemann, Theo. 1988. Preference laws for syllable structure and the explanation of sound change (with special reference to German, Germanic, Italian, and Latin). Berlin: De Gruyter Mouton.

Wang, William S-Y. 1968. Vowel features, paired variables, and the English vowel shift. Language 44(4): 695-708. 